\title{
Role of EMI and Resultant Impact on Career Development of Chinese Students
}

\author{
He Xiaoyong ${ }^{1}$, Wen Lixia ${ }^{2}$, Divyashreem Ravikiran Honavar ${ }^{1}$, Deng Yongzhong ${ }^{1}$ \\ ${ }^{1}$ International School, Jinan University, Guangzhou, China \\ ${ }^{2}$ International Business School, Jinan University, Zhuhai, China \\ Correspondence: He Xiaoyong, R322, International School, Jinan University, No.601 Huangpu Road West, \\ Guangzhou, Post Code: 510632, Guangzhou City, Guangdong Province, China. Tel: 86-0134-8027-9301. E-mail: \\ da128712@163.com
}

Received: March 13, 2017

Accepted: April 17, $2017 \quad$ Online Published: April 19, 2017

doi:10.5539/ass.v13n5p158

URL: https://doi.org/10.5539/ass.v13n5p158

\begin{abstract}
With the ever-changing trends in internationalization of higher education in the recent past, English has been adopted as an effective medium of instruction for many students in various universities all over the world. However, with all its merits, evidence shows that English medium of instruction (EMI) is not very much popular mode of learning in universities across mainland China.

This research is an endeavor to highlight the merits of EMI and its associate linkages to career development of Chinese students. While comparing with Chinese medium of instructions (CMI), the findings of this paper have suggested that EMI has a positive impact on the career development of students. Those students who have taken courses in English medium have received better jobs and more opportunities for fair career growth.

It is further argued that EMI not only assist the individuals in shaping their better future, but it also facilitates in providing efficient labor force for the growing economies. As part of globalization, large numbers of firms are pouring into China. Resultantly, various companies are vigorously searching for graduates with high level of English proficiency. To this end, the role of EMI programs is highly significant in providing right candidates for the corporate sector. Given the need of current employers, it is highly recommended to establish more EMI programs in Chinese institutions.
\end{abstract}

Keywords: EMI, CMI, Career Development, English Based Courses, Chinese Universities

\section{Introduction}

Ethnically, China is such a diverse country where students come from various regions, speaking varied languages and dialects. But despite of language barriers, everyone is communicating well and that is partly because of English language. Learning English has become a new passion among young Chinese university students. Students not only learn English at schools but also outside the campus, through the internet, from music, through computer games by watching movies and from television series. Many of these students are highly mobile and in most cases migrate abroad in order to pursue further higher education.

Very little work has been done in analyzing the comparative advantage of various medium of instructions in case of China. As more and more Chinese higher education institutions are adopting English as a medium of instructions (EMI), it is increasingly important to analyze the cost and benefits of this move. Hence, this research is geared to compare the Chinese medium of instruction (CMI) with English medium of instruction (EMI) and amylase the resultant impact on the career development of Chinese students in respect of job prospects, opportunities for further education in abroad and working for modern corporate sector.

As Chinese education system is going through a transformation, more emphasis is being placed on English as medium instructions. Research has proved that the use of English medium instructions in Chinese universities lead to a better career prospects for students in comparison with students having studied in Chinese medium of instructions. Thanks to the English medium of instruction, adapted in the Chinese universities, students have been able to go abroad and explore new avenues of career path.

English medium of instructions carries numerous advantageous. Just to name a few, it is highly beneficial in 
pursing higher education in abroad, it gives more opportunities to work with some of the world's biggest companies, people with better English proficiency are deemed to have higher salaries and more opportunities for career growth.

The quality of English medium of instruction in many Chinese universities is blow the par and that requires fundamental overhaul. The delivery of lectures, quality of instructors, teaching material and student's English proficiency all matters when it come to effective medium of instruction.

This paper aims to discuss the merits of English as an effective means of instruction in comparison with the Chinese medium of instruction and its associate linkages to the career development of Chinese students. The study is further organized as follows. In the next two sections, we will discuss the research design and the methodology. Section four covers the analysis and data interpretations, while section five offers findings and recommendations.

\section{Research Design}

English is the most popular medium of instruction all over the world. Despite its popularity, many universities have experienced difficulties in implementing the EMI. Chinese universities also face the same problem. In China, one of the issues that have generated debate is the proposed reforms of reducing the weight of English medium of instruction in Chinese Universities. This means, more weightage and more emphasis on Chinese medium of instruction rather than stress on English. On the contrary, numerous studies have suggested that the use of English medium instruction in Chinese universities leads to better career prospects of the students when compare to that of Chinese medium of instruction. Hence, this research is geared to compare the benefits and disadvantages of both medium of instructions in Chinese universities and the resultant impact on the career development of Chinese students.

\subsection{Research Design}

For this research, we have selected the International School of Jinan University (JNU) as the sample case for the EMI. It is worth to mention here that International School of JNU is one of the first Schools in mainland China to offer all courses in English. For this study, we have chosen undergraduate students from seven majors offered at International school (IS). The major disciplines are Finance, Certified General Accountants (CGA)-Canada, International Economics \& Trade, Public Administration, Clinical Medicine, Food Quality \& Safety and Pharmacy from Jinan University. For the estimates and analysis, we have used sampling techniques and the data is calculated through the IBM - SPSS" software. The sample population is based on the responses of 100 undergraduate students from the International School.

\subsection{Limitations of the Study}

It is imperative to note that this study has several limitations. Due to limited sampling size, the observations made for the small sample has been generalized to the graduates in China. However, several interactions on personal level have been attempted in order to get more accurate results. Owing to shortage of time, the research has been confined to few groups which presumably represent the majority of youth students enrolled in EMI programs in China.

\section{Research Methodology}

\subsection{Data Collection}

Table 1. International School students sectors-wise employment data (2005-2014)

\begin{tabular}{lllllllllll}
\hline YEAR & 2005 & 2006 & 2007 & 2008 & 2009 & 2010 & 2011 & 2012 & 2013 & 2014 \\
\hline Private Companies & 1 & 5 & 9 & 9 & 9 & 14 & 8 & 11 & 18 & 27 \\
Overseas Companies & 4 & 12 & 18 & 12 & 10 & 15 & 24 & 31 & 25 & 27 \\
SOE & 1 & 2 & 4 & 5 & 1 & 10 & 9 & 5 & 8 & 19 \\
Study Abroad & 5 & 5 & 13 & 11 & 9 & 11 & 31 & 31 & 37 & 35 \\
Study at Home & 0 & 1 & 6 & 4 & 5 & 5 & 10 & 11 & 9 & 9 \\
Civil Service & 0 & 1 & 3 & 6 & 2 & 3 & 5 & 2 & 3 & 4 \\
Public Institution & 1 & 1 & 1 & 2 & 1 & 2 & 4 & 6 & 8 & 4 \\
TOTAL & 12 & 27 & 54 & 49 & 37 & 60 & 91 & 97 & 108 & 125 \\
\hline
\end{tabular}

Source: Authors calculation based on International School Students Survey 2015

For this study, the data was mainly collected from the undergraduate students of International School (IS) of Jinan University, which is a typical case for the EMI program in China. As a comprehensive University, Jinan 
University offers various majors to students in English and Chinese. Historically, Jinan University has been the top destination for overseas students. Hence, in order to attract more foreign students, JNU has started offering more courses in English. To this end, Jinan University has established International School in 2001. Initially, the School has only two majors namely, International Economics \& Trade and Clinical Medicine taught in English. During 2001 to 2009, with every passing year, one more major was added. After the graduation, students of International Schools can find jobs easily partially due to the EMI program. As more students start enrolling at the International School because of its English medium of instructions, the School has started offering all courses in English.

3.1.2 Analysis: Frequencies:

\begin{tabular}{|c|c|c|c|c|c|c|c|}
\hline \multicolumn{8}{|c|}{ Statistics } \\
\hline & $\begin{array}{c}\text { Private } \\
\text { Companies }\end{array}$ & $\begin{array}{c}\text { Overseas } \\
\text { Companies }\end{array}$ & SOE & $\begin{array}{c}\text { Study } \\
\text { Abroad }\end{array}$ & $\begin{array}{l}\text { Study at } \\
\text { Home }\end{array}$ & $\begin{array}{c}\text { Civil } \\
\text { Servant }\end{array}$ & $\begin{array}{c}\text { Public } \\
\text { Institution }\end{array}$ \\
\hline Valid & 10 & 10 & 10 & 10 & 10 & 10 & 10 \\
\hline Missing & 0 & 0 & 0 & 0 & 0 & 0 & 0 \\
\hline Mean & 11.10 & 17.80 & 6.40 & 18.80 & 6.00 & 2.90 & 3.00 \\
\hline Median & 9.00 & 16.50 & 5.00 & 12.00 & 5.50 & 3.00 & 2.00 \\
\hline Mode & 9 & 12 & $1^{\mathrm{a}}$ & $5^{\mathrm{a}}$ & $5^{\mathrm{a}}$ & 3 & 1 \\
\hline Std. Deviation & 7.233 & 8.664 & 5.461 & 13.011 & 3.742 & 1.792 & 2.449 \\
\hline Skewness & 1.122 & .037 & 1.407 & .414 & -.286 & .185 & 1.134 \\
\hline $\begin{array}{l}\text { Std. Error of } \\
\text { Skewness }\end{array}$ & .687 & .687 & .687 & .687 & .687 & .687 & .687 \\
\hline
\end{tabular}

Correlation Analysis:

Descriptive Statistics

\begin{tabular}{cccc}
\hline & Mean & Std. Deviation & $\mathrm{N}$ \\
\hline Private Companies & 11.10 & 7.233 & 10 \\
Overseas Companies & 17.80 & 8.664 & 10 \\
SOE & 6.40 & 5.461 & 10 \\
Study Abroad & 18.80 & 13.011 & 10 \\
Study at Home & 6.00 & 3.742 & 10 \\
Civil Service & 2.90 & 1.792 & 10 \\
Public Institution & 3.00 & 2.449 & 10 \\
\hline
\end{tabular}

Source: Authors calculation based on International School Students Survey 2015

3.1.3 Data Set-2 Data:

\begin{tabular}{|c|c|c|c|c|c|}
\hline Evaluation From Graduates & $\begin{array}{l}\text { Fully } \\
\text { Agree }\end{array}$ & Agree & Unsure & Disagree & $\begin{array}{c}\text { Completely } \\
\text { Disagree }\end{array}$ \\
\hline Great help for development of English knowledge & 43 & 34 & 19 & 4 & - \\
\hline Not much help for career development & 17 & 36 & 28 & 19 & - \\
\hline Team management is much easier & 28 & 30 & 38 & 4 & - \\
\hline $\begin{array}{l}\text { Company is interested in English knowledge } \\
\text { background }\end{array}$ & 34 & 34 & 21 & 9 & 2 \\
\hline Lack of language knowledge & 15 & 34 & 26 & 25 & - \\
\hline Course structure is not fit to social environment & 11 & 19 & 32 & 38 & - \\
\hline Great help to find a job & 47 & 34 & 9 & 2 & - \\
\hline Great help for promotion & 38 & 38 & 18 & 4 & 2 \\
\hline If given a chance, would choose language course again & 100 & - & - & - & - \\
\hline Very helpful for higher studies & 81 & 17 & 2 & - & - \\
\hline Good for collecting international resources & 42 & 34 & 12 & 12 & - \\
\hline Teachers' English level is important & 62 & 28 & 2 & - & - \\
\hline Teachers' work background is important & 59 & 30 & 11 & - & - \\
\hline
\end{tabular}




\subsubsection{Analysis:}

Frequencies:

\begin{tabular}{|c|c|c|c|c|c|c|c|c|c|c|c|c|c|}
\hline \multicolumn{14}{|c|}{ Statistics } \\
\hline & $\begin{array}{l}\text { Great help for } \\
\text { development } \\
\text { of English } \\
\text { Language }\end{array}$ & $\begin{array}{l}\text { Not much } \\
\text { help for } \\
\text { career } \\
\text { development }\end{array}$ & $\begin{array}{c}\text { Team } \\
\text { management } \\
\text { is much } \\
\text { easier }\end{array}$ & $\begin{array}{l}\text { Company is } \\
\text { interested in } \\
\text { my English } \\
\text { knowledge } \\
\text { background }\end{array}$ & $\begin{array}{c}\text { Lack of } \\
\text { language } \\
\text { knowledge }\end{array}$ & $\begin{array}{l}\text { Course } \\
\text { structure is } \\
\text { not fit to } \\
\text { social } \\
\text { environment }\end{array}$ & $\begin{array}{l}\text { Great } \\
\text { help to } \\
\text { find a } \\
\text { job }\end{array}$ & $\begin{array}{l}\text { Great help } \\
\text { for } \\
\text { promotion }\end{array}$ & $\begin{array}{c}\text { If given a } \\
\text { chance, } \\
\text { would } \\
\text { choose } \\
\text { language } \\
\text { course } \\
\text { again }\end{array}$ & $\begin{array}{c}\text { Very } \\
\text { helpful } \\
\text { for } \\
\text { higher } \\
\text { studies }\end{array}$ & $\begin{array}{l}\text { Good for } \\
\text { collecting } \\
\text { international } \\
\text { resources }\end{array}$ & $\begin{array}{l}\text { Teachers' } \\
\text { English } \\
\text { level is } \\
\text { important }\end{array}$ & $\begin{array}{c}\text { Teachers' } \\
\text { work } \\
\text { background } \\
\text { is important }\end{array}$ \\
\hline Valid & 4 & 4 & 4 & 5 & 4 & 4 & 4 & 5 & 1 & 3 & 4 & 3 & 3 \\
\hline Missing & 1 & 1 & 1 & 0 & 1 & 1 & 1 & 0 & 4 & 2 & 1 & 2 & 2 \\
\hline Mean & 25.00 & 25.00 & 25.00 & 20.00 & 25.00 & 25.00 & 23.00 & 20.00 & 100.00 & 33.33 & 25.00 & 30.67 & 33.33 \\
\hline Median & 26.50 & 23.50 & 29.00 & 21.00 & 25.50 & 25.50 & 21.50 & 18.00 & 100.00 & 17.00 & 23.00 & 28.00 & 30.00 \\
\hline Mode & $4^{\mathrm{a}}$ & $17^{\mathrm{a}}$ & $4^{\mathrm{a}}$ & 34 & $15^{\mathrm{a}}$ & $11^{\mathrm{a}}$ & $2^{\mathrm{a}}$ & 38 & 100 & $2^{\mathrm{a}}$ & 12 & $2^{\mathrm{a}}$ & $11^{\mathrm{a}}$ \\
\hline $\begin{array}{c}\text { Std. } \\
\text { Deviation }\end{array}$ & 17.146 & 8.756 & 14.652 & 14.474 & 7.789 & 12.247 & 21.087 & 17.550 & & 41.956 & 15.362 & 30.089 & 24.173 \\
\hline $\begin{array}{c}\text { Std. Error of } \\
\text { Skewness }\end{array}$ & 1.014 & 1.014 & 1.014 & .913 & 1.014 & 1.014 & 1.014 & .913 & & 1.225 & 1.014 & 1.225 & 1.225 \\
\hline
\end{tabular}

Correlation Analysis:

a. Multiple modes exist. The smallest value is shown

\section{Descriptive Statistics}

\begin{tabular}{llll}
\hline & Mean & Std. Deviation & $\mathrm{N}$ \\
\hline Great help for development of English Language & 25.00 & 17.146 & 4 \\
Not much help for career development & 25.00 & 8.756 & 4 \\
Team management is much easier & 25.00 & 14.652 & 4 \\
Company is interested in my English knowledge background & 20.00 & 14.474 & 5 \\
Lack of language knowledge & 25.00 & 7.789 & 4 \\
Course structure is not fit to social environment & 25.00 & 12.247 & 4 \\
Great help to find a job & 23.00 & 21.087 & 4 \\
Great help for promotion & 20.00 & 17.550 & 5 \\
If given a chance, would choose language course again & 100.00 &. & 1 \\
Very helpful for higher studies & 33.33 & 41.956 & 3 \\
Good for collecting international resources & 25.00 & 15.362 & 4 \\
Teachers' English level is important & 30.67 & 30.089 & 3 \\
Teachers' work background is important & 33.33 & 24.173 & 3 \\
\hline
\end{tabular}

Source: Authors calculation based on International School Students Survey 2015

\section{Findings, discussion and suggestions:}

\subsection{Data Set-1}

- Our findings suggest that the number of students working in private companies have increased over the past few years. This is largely due to the increasing demand of English speaking people in the private sector.

- It is further argued that the large amount of people like to work in foreign companies mainly because of better pay and perks, opportunities for future growth and further chances of career development.

- The demand for English speaking graduates working in State Own Enterprises (SOE's) has gone up significantly recently. This proves that SOE's also prefer to recruit more graduates from English Medium Instruction based institutions.

- Our study has further confirmed that "study abroad" is another powerful reason why many Chinese students like to study in EMI institutions.

- The result of our survey has indicated that the number of people who choose to study in the home country went down gradually over the last couple of year. On the contrary, the number of students study abroad have gone up steadily partly due to better economic conditions and the introduction of EMI programs in many Chinese institutions. 
- Addionally, our results shows that International School graduates preference for working in government sector and civil service has declined with every passing year. Several reasons could be attributed to this trend. Some students believe working in government sector is unrewarding as the sector offers less salaries and chances for promotions are relatively slow. Whereas, private sector is more efficient, lucrative and carries fair chances of promotions.

- Research points out that the number of graduates working in public limited companies has fallen notably which is mainly due to rapid emergence of domestic private sector and influx of international companies in mainland China.

- The correlation analysis confirms that the variables chosen from the comparative analysis positively match with the introduction of EMI program introduced at the International School (IS). It is concluded that the English Medium Instruction (EMI) program is very instrumental in securing better jobs for many IS students. Hence, we strongly recommend to establish more EMI based programs throughout China.

\subsection{Data Set-2}

- The research proves that maximum number of respondents fully agreed that EMI is useful in knowledge development and that provides more opportunities for career growth. Therefore, more instructors are encouraged to deliver lectures in English.

- Many respondents consider the EMI is not helpful in career growth if the candidates have low level of English proficiency. Besides, success of any EMI program is not merely based on medium of instructions, rather it depends on other several factors, including, the quality of instructors, modernized syllabi, selection of courses and the learning abilities of students.

- Most respondents were not sure whether the team management gets improve through the EMI based programs.

- Several respondents believed that the EMI not essentially guarantee to secure a better position in top companies. As a matter of fact, different companies have their own selection criteria for hiring suitable candidates. Hence, apart from other conditions, medium of instructions and candidate's English proficiency also counts when it comes to recruitment.

- Likewise, many respondents consider, the EMI programs are not very popular and effective in many institutions throughout China. Partially, because of student's poor background in English. As is well know, in many parts of China, in numerous primary schools and colleges, there is dire need of qualified English instructors.

- While, the majority of respondents disagree that students graduated from EMI based institutions would have a comparative advantage over Chinese medium of instructions gradates, when it comes to hiring for corporate sector. The argument is Chinese corporate sector is such a large and diverse that it absorbs all kind of candidates irrespective of their educational background, skills, degrees and working experience etc.

- Nearly half of the respondents agreed that English medium of instruction would help them greatly in finding better jobs, as recently, most of the employers and well known companies in China are keen to recruit graduates from EMI based institutions.

- Similarly, large numbers of respondents believed that EMI is instrumental in jobs hunting, personal career development and new opportunities for future growth.

- Majority of the respondents have agreed in principal, if they have been given a second chance, they would still consider to study in EMI programs. As it provides more knowledge and opportunities for fair career growth when compared with the Chinese medium of instructions.

- Likewise, more than half of the respondents fully agreed that English medium of instruction facilitate them greatly in seeking studies abroad. As a matter of fact, for studying abroad, all non-English speaking students are required to have high level of English proficiency. In most of the cases, they need to pass IELTS or TOEFL. To this end, EMI programs support students to a great extent in improving their English level.

- Almost half of the respondents fully agreed that English medium instruction would help them in improving their connections with foreigners. This may be due to the reason that they are required to communicate or interact with various communities and inter-cultural people who may not understand Chinese language very well. 
- More than half of the respondents fully agreed that instructors own English proficiency is very important in delivering lectures and communication students successfully.

- Most of the respondents believe that instructor's personal educational background is vital in transmitting knowledge to students in an effective way. That is particular very important in China as many Chinese students face difficulties in understudying lectures in English. Resultantly, we few students speak in the class and ask questions in class room.

- But for factors like English medium instruction is not of much help for career development, company is interested in the graduates' English language knowledge, and negative correlation is found in the analysis.

- Even though the factor "if given a chance, would choose language course again" has a total negative correlation, it is a good sign that the English medium instruction has a positive impact on the career development of Chinese students.

\subsection{General Discussion}

- Most of graduates chose to work in private companies or overseas companies. Likewise, many companies also prefer to hire people having graduated from EMI Programs. Companies believe employees with better English background will have comparative advantage in understanding the latest trends in the corporate sector. And it also expands their communications skill in interacting with wider audience.

- The results of our analysis have suggested that the use of English medium of instruction has very significant impact on the career development of Chinese students. Hence, more EMI programs possibly introduced in Chinese institutions. Initially, we recommend introducing more EMI Programs at undergraduate level and gradually upgrade to postgraduate and $\mathrm{PhD}$ level.

\section{Conclusion}

Medium of instruction is very important in effective learning. Those instructors who have better communication skills and good command over English; they are more likely to be successful in transmitting knowledge to students. Though the impact of learning is largely based on instructor's own abilities of teaching, yet medium of instructions play a vital role. In Chinese students case, there has been a mixed of rejoinder. Many students consider English medium of instruction is more successful in learning and that broadens their horizon of knowledge, offers more opportunities for overseas studies, provide more chances of working in international companies and helping in reshaping their future career. On the converse side, some students believe, Chinese medium of instruction is more effective due to various reasons. To this end, one of the powerful arguments is that people understand much better in "mother tongue". Historically, those countries who have adopted national langue as their medium of instruction have been more successful in cultivating good graduates with sound knowledge.

But with the globalization, need for English proficient candidates is growing at an accelerate rate. As China is transforming from developing to developed country, large number of companies-domestic and international, are still actively searching for candidate with good proficiency of English. On the other side, as China is getting more international, large numbers of foreign students are seeking admissions into Chinese institutions. While, the capacity of Chinese universities and institutions to offer programs English is limited. As our research confirms, there is huge potential for EMI Programs in China.

As discussed in the earlier part of this paper, it is observed that comparatively, there is less emphasis on the English medium instruction or English based courses in the Chinese Universities despite of growing demand for these programs. The analysis of this research has confirmed that many graduates like to study in English medium of instruction programs due to variety of reasons. As a matter of fact, numerous Chinese students, after the graduation, like to go abroad for further higher studies. Besides, majority of the students want to study in EMI programs mainly for finding a better job in well established companies where they can get a greater exposure to international environment. These encounters re-affirm student's belief in EMI programs which eventually lead them to a better career development path.

China has received tremendous benefits from the overseas returnee graduates. Due to international exposure, better knowledge, skills and trainings, they lead the corporate sector and contributing considerably for the better of greater China.

\section{Acknowledgements}

The paper reported here is sponsored by the project of 2016 Guangzhou Philosophy and Social Science "the 13th Five-Year Plan", Project name: Research on the Cultivation of Craftsman Spirit and Career Identity of College 
Students, Project Grant No.: 2016MZXQ01.

The research is also phased result by the project of Ideological and Political Education of Jinan University, Project name: Research on Positioning and Development of Creative and Innovative Talents, Project Grant No.: JNUSZ201611.

The research is also phased result by the Cultivating Project of Guangdong Education Achievement Award (Higher Education), Project name: Construction of a Multi Subject English and Teaching Demonstration Platform, Project Grant No.:55610125.

\section{References}

Gao, X. S. (2013). Language Learning Strategies Used by Asian Students in English-medium Universities. Shanghai: Contemporary Foreign Languages Studies.

Haugen, E. (2006). Language conflict and language planning: The case of modern Nowegian. Cambridge. MA: Harvard University Press. Hong Kong SAR government.

He, X. Y. (2015). Language Interaction and the Influence of the Chinese Language. Hefei: Academics in China.

Lai, P., \& Byram, M. (2003). The politics of bilingualism: A reproduction analysis of the policy of mother tongue education in Hong Kong after 1997. UK: Compare: A Journal of Comparative and International Education.

Lu, Deng-guang \& Lu, Deng-zhao. (1992). A Study on the Simplified Chinese Characters on the Two Sides of the Taiwan Straits. Taipei: Student Book Company.

Politzer, R., \& McGroarty, M. (1985). An exploratory study of learning behaviors and their relationship to gains in linguistic and communicative competence. TESOL Quarterly.

Stern, P. (1975). What we can learn from good language learners? Canadian Modern Language Review.

Wei, Z. (2007). Medium of Instruction in Secondary Education in Post-Colonial Hong Kong: Why Chinese? Why English? Working Papers in Educational Linguistics.

Wen, L. X. (2016).Off-campus Entrepreneurship Tutorial System in China. Asian Social Science.

Wilkinson. (2008). English-taught Courses: Principles and Practice. English in Academia: Catalyst or Barrier.

\section{Copyrights}

Copyright for this article is retained by the author(s), with first publication rights granted to the journal.

This is an open-access article distributed under the terms and conditions of the Creative Commons Attribution license (http://creativecommons.org/licenses/by/4.0/). 